http://jmscr.igmpublication.org/home/ ISSN (e)-2347-176x ISSN (p) 2455-0450 crossref DOI: https://dx.doi.org/10.18535/jmscr/v9i3.07

\title{
COVID 19 Reinfection: A Case Report
}

\author{
Author \\ Farha Ahmed Payyanil Karlath \\ Junior Resident In Internal Medicine, Government Medical College, Kannur, Kerala \\ Corresponding Author \\ Farha Ahmed Payyanil Karlath
}

\begin{abstract}
Coronavirus disease 2019 (COVID-19) is a pandemic disease spread globally.It is caused by the SARS$C O V-2$ virus surface spike protein binding to the human angiotensin-converting enzyme 2 (ACE2) receptor, that is expressed in the lung (type 2 alveolar cells), heart, intestinal epithelium, vascular endothelium, and kidneys, providing a mechanism for multi-organ dysfunction. The median incubation period time is 4 to 5 days and $97.5 \%$ of patients will exert symptoms within 11.5 days1.Reinfection by COVID 19hs been documented in various parts of the world and is quite alarming. I am reporting a probable case of reinfection by SARS CoV 2 at Government Medical College, Kannur, Kerala.
\end{abstract}

\section{Case Details}

A 50 year old male, known case of type 2 diabetes mellitus, presented with fever and cough for 8 days and breathlessness for 2 days.

Fever was intermittent, not associated with chills and rigors. Cough was not associated with expectoration, with no diurnal or postural variation. Breathlessness was mostly exertional. No history of chest pain or orthopnoea or paorxysmal nocturnal dyspnoea.

Patient was a diabetic for past 3 years and under diet control, not on any medications.

Patient was found to have COVID 19 infection 4 months back and was categorised as COVID 19 category A since he was asymptomatic then. He was tested for COVID 19 by RT PCR on $12 / 5 / 2020$ since he was a high risk primary contact and was tested positive. He was declared COVID 19 negative after two consecutive naso- pharyngeal and throat swabs were tested negative by RT PCR on 20/5/2020 and 23/5/2020.

On examination, patient was conscious, oriented, dyspnoeic at rest.

BP:130/90mm of $\mathrm{Hg}$. PR:72/m, regular.

RR:24/min SpO2 :85\% on room air,92\% on low flow $\mathrm{O} 2$

Chest auscultation revealed bilateral crackles.

In view of worsening breathlessness and increased work of breathing, patient was kept on high flow nasal oxygen and then, subsequently on non invasive ventilation (CPAP) and he was started on Remdesivir, Steroids, low mlecular weight heparin. Patient improved symptomatically and was able to maintain a saturation of about $92 \%$ with $\mathrm{O} 2$ at $5 \mathrm{~L} / \mathrm{min}$. 


\section{Investigations}

- Nasal swab Rapid Antigen Test on 23/9/2020 : Positive

- Confirmation by nasal and oropharyngeal swab RT PCR on 23/9/2020 at GMC Kannur and NIV, Pune : Positive
- Tables 1 and 2 show the basic blood investigations and serial inflammatory markers, respectively.

Table 1: Basic Blood Investigations

\begin{tabular}{|l|c|c|c|}
\hline Investigations & Values & Investigations & Values \\
\hline Hemoglobin & 13700 & FBS & 122 \\
\hline Total Count & 10700 & Glycosylated Hb & $10.8 \%$ \\
\hline Neutrophils & $7.2 \%$ & Albumin/Globulin & $4.1 / 2.4$ \\
\hline Lymphocytes & $17.1 \%$ & Urea/Creatinine & $28 / 1.0$ \\
\hline Abslute Lymphocyte count & 1800 & URE & Normal \\
\hline ESR & 59 & Potassium & 4.6 \\
\hline Platelet & 266000 & Sodium & 138 \\
\hline
\end{tabular}

Note: Data from clinical laboratory, Government medical college, Kannur

Table 2: Serial Inflammatory Markers

\begin{tabular}{|l|c|c|c|c|}
\hline & $24 / 9 / 2020$ & $25 / 9 / 2020$ & $26 / 9 / 2020$ & $28 / 9 / 2020$ \\
\hline CRP & 156.4 & 108.4 & 86.4 & 66 \\
\hline LDH & 958 & 882 & 793 & 557 \\
\hline Ferritin & 1808 & & 980 & 854 \\
\hline
\end{tabular}

Note: Data from clinical laboratory, Government medical college, Kannur

\section{Chest X Ray}

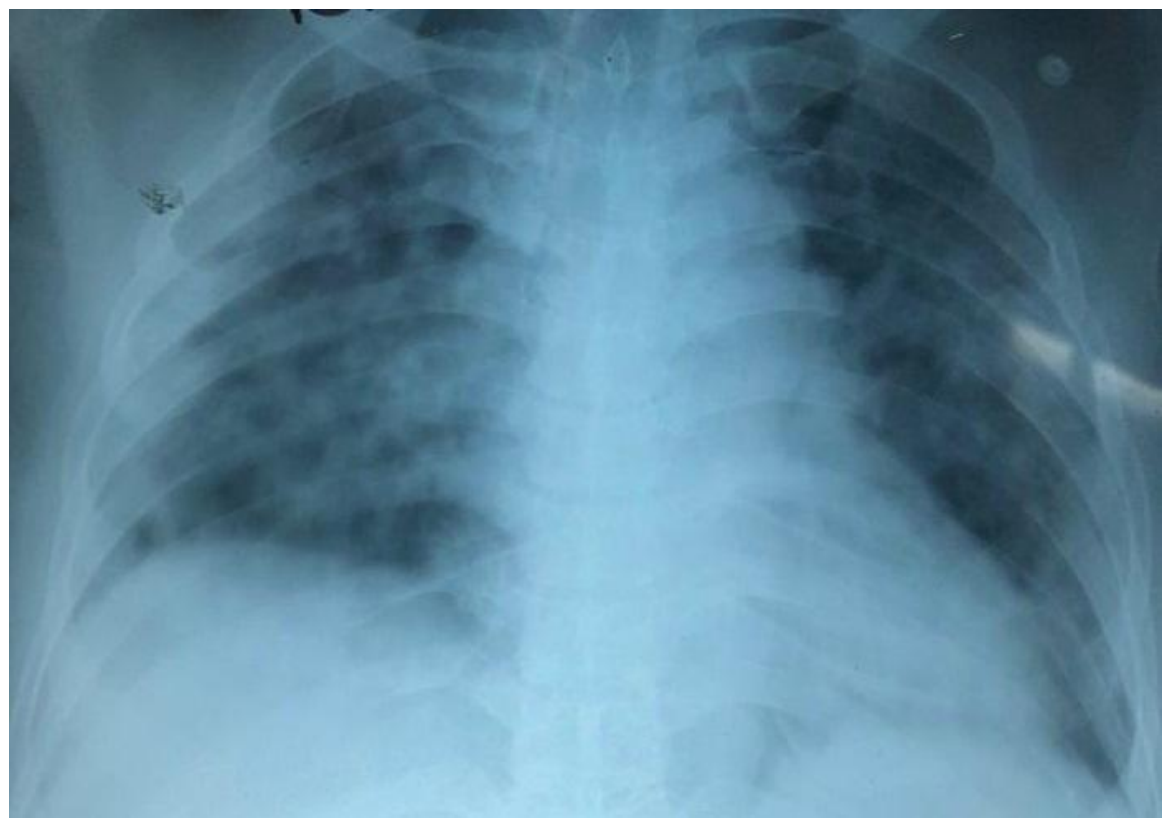

Chest $\mathrm{X}$ ray on day of admission 


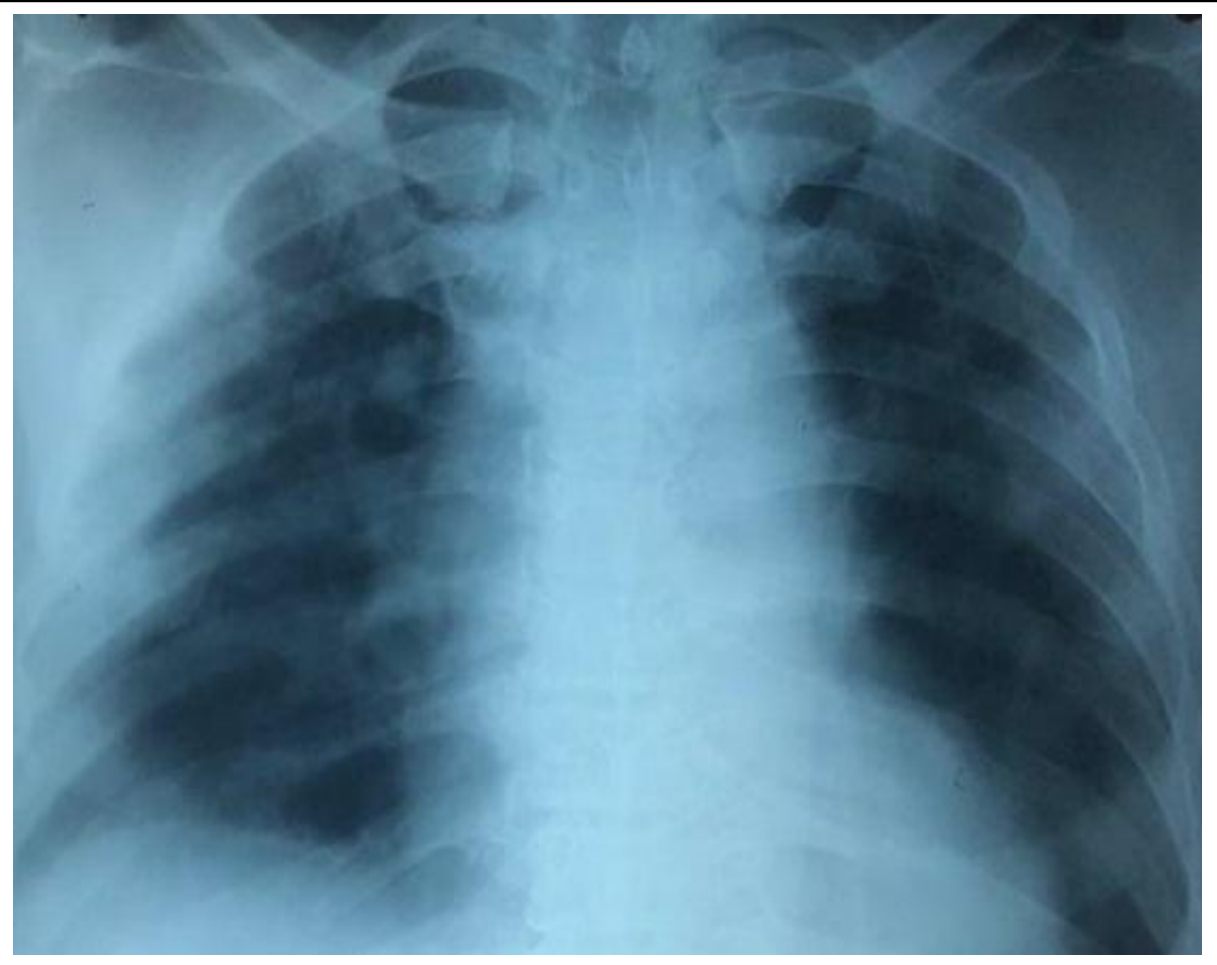

Chest $\mathrm{X}$ ray taken 4 days after admission

\section{HRCT Chest}

- Multifocal bilateral asymmetrical predominantly peripheral ground glass densities with slight posterior predominance, seen in bilateral lung fields. Relatively prominent vessels seen along the areas of ground glass opacities -CORARDS 6

- Small subcentimetric mediastinal lymph nodes

\section{Diagnosis}

COVID 19 reinfection, Type 2 Diabetes Melitus

\section{Discussion}

WHO declared Novel Coronavirus Disease (COVID-19) outbreak as a pandemic on 11 March 2020, and reiterated the call for countries to take immediate actions and scale up response to treat, detect and reduce transmission to save people's lives. Person-to-person transmission of the infection led to the isolation of patients and were subsequently administered a variety of treatments. There have been extensive measures to reduce person-to-person transmission of COVID-19 implemented to control the current outbreak.
Symptoms of COVID-19 infection appear after an incubation period of approximately 5.2 days $^{[2]}$. The period from the onset of COVID-19 symptoms to death range from 6 to 41 days with a median of 14 days $^{[3]}$. Most common symptoms at onset of COVID-19 illness are fever, cough, and fatigue, while other symptoms include sputum production, headache, haemoptysis, diarrhoea, dyspnoea, and lymphopenia

Various postulations regarding the pathogenesis of Covid 19 have been proposed and various research are going on. Coronaviruses are enveloped, positive-sense, single-stranded RNA viruses of $\sim 30 \mathrm{~kb}$. Life cycle of the virus with the host consists of the 5 steps: attachment, penetration, biosynthesis, maturation and release. Once viruses bind to host receptors (attachment), they enter host cells via endocytosis or membrane fusion (penetration). Once viral contents are released inside the host cells, viral RNA enters the nucleus for replication. Viral mRNA is used to make viral proteins (biosynthesis). Then, new viral particles are made (maturation) and released. Coronavirus consists of four structural proteins; Spike (S), membrane (M), envelop (E) and nucleocapsid $(\mathrm{N}){ }^{[4]}$. Angiotensin converting enzyme 2 (ACE2) 
was identified as a functional receptor for SARS$\mathrm{CoV}^{[5]}$. ACE2 expression is high in lung, heart, ileum, kidney and bladder.

The symptoms of those infected with SARS-CoV2 ranges from minimal symptoms to severe respiratory failure with multiple organ failure. On Computerized tomography (CT) scan, pulmonary ground glass opacification can be seen even in asymptomatic patients. $T$ cell responses are initiated by antigen presentation via DCs and macrophages.

My patient who is a case of reinfection presented with more severe symptoms. More light regarding the pathogenesis and treatment of a case of reinfection has to be shown.

\section{Relevance}

COVID 19 incidence is increasing tremondously worldwide and the uncertainty regarding preventive and therapeutic measures is further disappointing to the scientific community. Reinfections have been a myth and hence have not been addressed properly. However, patients like ours can be a common scenario in no time and hence, active discussions regarding the same have to be encouraged and proper treatment protols have to be formulated for reinfection at the earliest. Evaluating whether reinfections are more severe clinically is also the need of the hour.

\section{Ethical Consideration}

Informed consent was taken from the patient for publication of medical reports and relevant history without revealing identity.

Conflict of Interest: None declared

Ethical Approval: Not required

\section{References}

1. Clerkin KJ, Fried JA, Raikhelkar J, et al: : COVID-19 and Cardiovascular Disease. Circulation. 2020; 141(20): 16481655
2. Q. Li, X. Guan, P. Wu, X. Wang, L. Zhou, Y. Tong, et al.Early transmission dynamics in wuhan, China, of novel coronavirusinfected pneumonia

3. W. Wang, J. Tang, F. WeiUpdated understanding of the outbreak of 2019 novel coronavirus (2019-nCoV) in Wuhan, China J. Med. Virol., 92 (4) (2020), pp. 441447

4. Bosch B.J., van der Zee R., de Haan C.A., Rottier P.J. The coronavirus spike protein is a class I virus fusion protein: structural and functional characterization of the fusion core complex. Journal. 2003;77:8801-8811.

5. Li W., Moore M.J., Vasilieva N., Sui J., Wong S.K., Berne M.A., Somasundaran M., Sullivan J.L., Luzuriaga K., Greenough T.C., Choe H., Farzan M. Angiotensin-converting enzyme 2 is a functional receptor for the SARS coronavirus. Journal. 2003;426:450-454. 